ROCZNIKI PEDAGOGICZNE

Tom 12(48), numer $4-2020$

DOI: https://doi.org/10.18290/rped20124-4

TERESA OLEARCZYK

\title{
CISZA W DIALOGU RODZINNYM
}

\section{WPROWADZENIE}

Na początku było Słowo... Panowała cisza, by słowo mogło wybrzmieć... „Cisza” w Ewangelii występuje 900 razy. Słuchaj Izraelu...

Zagadnieniem ciszy zajmowała się filozofia, było ono obecne w kulturze, tradycji i wychowaniu (zachowaniu). W pedagogice Maria Montessori wskazywała na potrzebę obecności ciszy w procesie edukacji. Trudno jest mówić o ciszy, nie dotykając osoby ludzkiej, jakkolwiek cisza może istnieć bez człowieka, zaś człowiek pozbawiony ciszy cierpi fizycznie i psychicznie. Nie mówię o ciszy absolutnej, sensorycznej, bo ta jest równie szkodliwa jak hałas - zabija. Podejmuję problematykę ciszy jako elementu refleksji i kultury życia rodzinnego i społecznego.

Współcześni ludzie zaangażowani w rozwiązywanie problemów zawodowych, konsumpcję, ,zagubieni” w chaosie codzienności, coraz mniej mają czasu dla rodziny i dla siebie, przywykli do zgiełku i pośpiechu. Brak ciszy zaowocował nie tylko zmęczeniem, stresem, ale także chorobami. Cisza jest niezbędna, by usłyszeć słowo, zrozumieć je, nawiązać relacje z drugim człowiekiem i nie stracić kontaktu z sobą samym, ze swoim wnętrzem.

$\mathrm{W}$ pedagogice tematyka związana $\mathrm{z}$ ciszą podejmowana była przez wspomnianą już Marię Montessorii. Warunki życia spowodowały, że w ostatnim czasie zainteresowanie ciszą powróciło.

Celem niniejszego artykułu jest przedstawienie teoretycznych założeń związanych z ciszą, zarówno w sensie ogólnym, jak i w dialogu małżeńskim i rodzinnym.

Dr hab. Teresa OlEARCZYK, prof. KAAFM - Wydział Psychologii, Pedagogiki i Nauk Humanistycznych, Krakowska Akademia im. A.F. Modrzewskiego; adres do korespondencji: ul. Białoruska 19/14, 30-648 Kraków; e-mail: teresa.olearczyk@onet.pl; ORCID: https://orcid.org/00000001-6660-2379. 
Problem pracy wyartykułowany $\mathrm{w}$ tytule wyznacza obszar i przedmiot badań. Głównym problemem niniejszej publikacji jest znalezienie odpowiedzi na pytanie: Jaką wartość wprowadza cisza w dialogu małżeńskim i rodzinnym?

Główny program badawczy zostaje doprecyzowany przez szereg następujących pytań szczegółowych: Jak rozumieć ciszę? Jaka jest jej istota (Etos słowa i bogactwo ciszy)? Jakie czynniki wpływają na obecność ciszy w rodzinie? Jakie znaczenie ma cisza w kulturze dialogu? Co oznacza milczenie dialogowe? Jakie są oblicza ciszy, milczenia? Czy i jak cisza może pomagać w procesie wychowania i pracy nad sobą?

Problematyka badawcza pozwala wskazać główne cele analiz: teoretyczne, poznawcze i praktyczne.

Skomplikowana i niejednoznaczna, niejednorodna postać ciszy (fenomen) jest ponadczasowa i obecna w życiu człowieka. Cisza pełni rolę refleksyjną, sprzyja koncentracji, pomaga rozumieć i tłumaczyć sens życia i działania ludzkiego, pozwala zapanować nad emocjami, prowadzi do kontemplacji.

Funkcjonowanie rodziny współczesnej jest uwarunkowane wieloma czynnikami, zmieniającymi się $\mathrm{w}$ dynamicznym tempie. Wzajemne relacje międzyosobowe rozgrywają się w szerszym kontekście społecznym, który wzajemnie dotyka i formuje jednostkę. Nie jest to zależność determinująca ani dla jednostki, ani dla społeczeństwa, niemniej wzajemne przenikanie się różnych tendencji znajduje odbicie w obu stronach interakcji. Środowisko zewnętrzne wysyła coraz więcej sygnałów, które zaburzają lub wręcz zagrażają harmonii życia rodzinnego.

Rozmyślanie nad ciszą, jak i nad milczeniem było i jest inspiracją myśli filozoficznej wszystkich czasów. Trudno nieraz je oddzielić i rozważać ich autonomiczne znaczenie w kontekście stanów ludzkiej egzystencji i ich wzajemnych relacji.

Celem teoretycznym rozprawy jest ustalenie specyfiki ciszy.

Celem poznawczym pracy jest wydobycie istoty ciszy, odnoszącej się do troski o rozwój moralno-społeczny życia rodziny oraz wskazanie na wychowanie moralne i pewne elementy niezbędne w procesie wychowania młodego pokolenia. 


\section{CZYNNIKI WPŁYWAJĄCE NA OBECNOŚĆ CISZY W RODZINIE}

Poważnym zagrożeniem w funkcjonowaniu współczesnej rodziny jest hałas i chaos, który towarzyszy codzienności, utrudnieniem niski poziom kultury pedagogicznej rodziców, a także nadpobudliwość psychoruchowa dzieci.

Relacje międzyludzkie odbywają się zarówno przez słowo, jak i przez ciszę. Słowo i cisza są sobie wzajemnie potrzebne, komplementarne, choć każde wyraża się nieco inaczej.

Cisza jest elementem komunikacji, zawiera wiele komunikatów niewerbalnych, jest warunkiem budowania dobrych, zdrowych relacji, wymaga od nas pewnego wysiłku (Wieja, 2002, s. 136). Dotyk, gestykulacja, wycofanie się, marszczenie brwi, patrzenie na drugą osobę, to formy niewerbalnej komunikacji w ciszy (Wieja, 2002, s. 83).

Stanisław Kawula podkreśla znaczenie świadomości wychowawczej rodziców (Kawula, 1975) jako formę odzwierciedlania przez nich spraw związanych z wychowaniem własnych dzieci, na którą składa się określony zasób wiedzy pedagogicznej i wypływające $z$ niej praktyczne działanie wychowawcze wykorzystujące ciszę i milczenie jako środek wychowawczy i terapeutyczny.

Najgorszym, co może się zdarzyć w rodzinie, to cisza obojętności, cisza braku solidarności, to złowroga cisza ukrywająca dramaty. Warto więc podjąć trud i poprzez dialog zbudować ciszę swojego domu. Proces tworzenia ciszy $\mathrm{w}$ rodzinie, która jest niezbędna dla normalnego funkcjonowania poszczególnych jej członków, dokonuje się z uwzględnieniem czynników jemu sprzyjających.

\section{A. Potrzeba ciszy i milczenia}

Cisza jest kluczem do wielu zagadnień, także pedagogicznych. Czasy, w których żyjemy, wyostrzają problematykę zarówno ciszy, jak i milczenia, wskazując na możliwości stosowania ich w procesie wychowania. Milczenie przychodzi znacznie trudniej, a jeszcze trudniej ujawnia się sens podejmowanych działań w ciszy. Hałas może zagłuszyć nie tylko brzmienie i sens wypowiadanych słów, ale także spokój wewnętrzny. Aby słowo usłyszeć i zrozumieć, potrzebna jest cisza i milczenie. W odkrywaniu potrzeby ochraniania się przed codziennym wrzaskiem, potrzebna jest nowa samoświadomość, że „milczenie nie jest sprawą wyłącznie indywidualną, lecz ma szerszy, społeczny wymiar. Dzisiaj stało się zagadnieniem z zakresu ochrony środowiska naturalnego”. „W skupiskach wielkomiejskich prowadzi się pomiary hałasu - pisze dalej o. Maria Szczepan OCR - wyznaczając w decy- 
belach jego granice, których przekroczenie zagraża fizycznemu i psychicznemu zdrowiu społeczeństwa. Przestrzeganie ciszy weszło do przepisów dotyczących bezpieczeństwa i higieny pracy. [...] W lasach, nad jeziorami i nad morzem tworzy się sfery ciszy, zarówno dla uszanowania praw drugiego człowieka do rekreacji, odpoczynku, jak i dla ratowania zagrożonych warunków rozwoju świata zwierzęcego" (Szczepan, 1984, s. 15).

Trzeba zaznaczyć podstawową cechę dystynktywną: cisza nie jest milczeniem. Zarówno milczenie, jak i cisza są zjawiskami mającymi podobne właściwości, czasem występują równocześnie, często używane są zamiennie. Milczeć można w hałasie, podczas gdy cisza w hałasie ginie. Wszystkie działania ludzkie są w refleksyjny sposób związane z bezpośrednią sytuacją, w której zachodzą.

Stefan Niedziałkowski podkreśla, że „milczenie odnosi do stanu duchowego będącego owocem głębokiej mądrości i wrażliwości, wyprzedza wypowiedziane słowa [...] istnieje poza słowami. Uwidacznia się w ludzkich postawach, łączy ludzi i jest wyrazem ludzkiej świadomości” (Niedziałkowski, 1998, s. 18-19).

Cisza dotyczy sposobu życia, podczas gdy milczenie jest spoiwem łączącym nasze postawy i czyny, jest świadomą obecnością (Chryssavgis, 2007, s. 43). Cisza obecności w relacji dwóch osób jest czymś bardzo osobistym, zacieśnia więź, ma głęboki sens, nie jest próżnią. Skupienie i cisza są elementami dialogu, sprzyjają zbliżeniu i jedności. Chodzi o zjednoczenie osób, świadomość tożsamości (już nie każdy oddzielny „ja”, ale „my”), która przejawia się w obecności, czyli w relacji ze współmałżonkiem. Spotkanie konstruktywne, uporządkowane ma przede wszystkim miejsce w dialogu rodzinnym. Obecność ciszy w dialogu małżeńskim jako wyraz obecności osoby, stanowi przestrzeń bliskości, przepełnionej gestami, wyraża zaufanie, miłość, jest znacznie bardziej wymowna niż wypowiadane słowa, wymaga większej znajomości drugiej osoby. Cisza może być wspaniałą towarzyszką osób, może wypełniać czas, sprawiać wiele radości, jeżeli umiejętnie się $\mathrm{z}$ niej korzysta. Komunikaty niewerbalne przekazywane w ciszy mogą być czytelne tylko dla danego małżeństwa.

Cisza warunkuje budowę dobrych, zdrowych relacji, wymaga jednak pewnego wysiłku, by emanowała czytelnymi komunikatami niewerbalnymi (Wieja, 2002, s. 136). Nieraz jest dynamiczna, buduje napięcie, milczenie zaś jest subtelną czynnością mającą swoją wymowę. J. Chmielewska uważa, że cisza jest o wiele trudniejsza do zniesienia dla kobiet niż dla mężczyzn, kobiety potrzebują więcej komunikatów werbalnych (J. Chmielewska, 1998, s. 17), jest równocześnie wyrazem kultury bycia. 


\section{B. Etos slowa i bogactwo ciszy}

Słowo i cisza są sobie wzajemnie potrzebne, komplementarne, choć każde oddziałuje i wyraża sens nieco inaczej. Słowo współcześnie stało się czymś tanim, często nie buduje już wzajemnych relacji, a nawet nieraz rani. Słowo kłamliwe, fałszywe, nieprawdziwe zadaje ból, rujnuje człowieka. W słowie zawiera się rzeczywistość tego, kto mówi, jednak by mogło właściwie wybrzmieć, musi być słuchane. Poprzez słowo człowiek kreuje pewną rzeczywistość. Wiele staje się przez słowo: dobrego lub złego. Słowo ustanawia relacje międzyludzkie, zbliża lub oddala.

Obecność słowa i milczenia kształtują się według paradygmatu dziejowego, istnieją obok siebie przemiennie, wzajemnie ze sobą współgrają, są sobie potrzebne. Słowo kreuje pewną rzeczywistość, wypowiedziane wpływa także, a może przede wszystkim, na rozwój emocjonalny dziecka. Słowo ma swoją moc - nagradza, napomina, wyraża miłość, uznanie. Wraz ze słowem łączy się słuchanie (słowo i cisza), w ciszy przyjmuje się słowo. Może ono wiele zmienić w zachowaniu i postępowaniu człowieka, zależnie od tego, czy słowo staje się narzędziem błogosławieństwa czy przekleństwa.

Cisza jako brak słowa i cisza zamiast słowa mają dwa różne znaczenia. W słowie zawiera się rzeczywistość tego, kto mówi. Istnieje taki rodzaj ciszy, która zapada, gdy brakuje nam właściwego słowa, odpowiedniego określenia, i cisza, która rozbrzmiewa zamiast słowa - ta jest bardzo wymowna i znacząca. Może stać się przestrzenią, w której egzekwujemy swoje prawa, wymuszamy je na drugim człowieku.

Bogactwo ciszy objawia się w tkwiącej w niej mocy zrozumienia własnego istnienia, poznawania prawdy o sobie i sensie swojej egzystencji. Cisza to także ukojenie wzburzonych emocji, daje możliwość powstrzymania się od pochopnych decyzji i reakcji. Milczenie natomiast jest aktem woli, umiejętnością zapanowania, niewypowiadania słów, zatrzymania. Pomaga kontrolować swoje własne emocje.

Zarówno pozytywne, jak i negatywne emocje pojawiają się przede wszystkim w wyniku doświadczeń z dzieciństwa. Wszystko, co dziecko widzi i słyszy, jest przez podświadomość przyjmowane jako fakt. Negatywne emocje tworzą się w konsekwencji doznawanej destruktywnej krytyki i braku milości. Nieumiejętność wyrażania i okazywania uczuć, brak miłości jest podstawową przyczyną większości problemów emocjonalnych w dorosłym życiu. Wspomnienia z dzieciństwa dotyczą relacji i atmosfery panującej w domu rodzinnym. 
Istnieje jednak taki rodzaj ciszy, która nie buduje więzi i może ranić drugiego człowieka. Kiedy zapada między osobami, z którymi nie łączy głęboka relacja, jest trudna i niewygodna. Wydaje się, że krótki czas takiej ciszy przedłuża się w nieskończoność i do niczego nie prowadzi. Może stać się przestrzenią, w której egzekwuje się swoje prawa poprzez wymuszanie. Tak dzieje się, gdy jesteśmy w konflikcie („,ciche dni”), czujemy się zranieni. Uporczywe milczenie może służyć jako sposób osiągnięcia jakiegoś celu, może być wymierzone przeciwko drugiemu człowiekowi. Nosimy w sercu urazę, wtedy najczęściej unikamy dialogu, a miejsce rozmowy zastępuje milczenie, które nie rozwiązuje problemu. Małżonkowie potrzebują rozmowy, której towarzyszy cisza, a nie ciszy, która niszczy. Cisza ma zatem nieskończenie wiele znaczeń i wymiarów.

\section{ISTOTA I ZNACZENIE DIALOGU}

Z zagadnieniem ciszy i milczenia związane jest $\mathrm{z}$ pytaniem o początek dialogu. Według Bogdana Barana „Dialog, a tym samym człowieczeństwo spotkania się ' Ja' i 'Ty' rozpoczyna się wtedy, kiedy w jedną i drugą stronę wypowiadane słowa stają się środkiem do tego, aby szukać drugiego człowieka, by mu pomoc w wyjściu z kłopotu, jaki jeden człowiek sprawia z konieczności drugiemu" (Baran, 1991, s. 155). Dialog jest warunkiem pokoju, umożliwieniem trwania, pozwala na podjęcie trudu zrozumienia drugiego człowieka, które polega na tym, że „trzeba mu pozwolić być, trzeba wejść z nim w dialog, zapytać, co myśli, szukać odpowiedzi, gdy zada pytanie” (Tischner, 1982, s. 493).

Dialog nabiera wartości, sensu w określonym kontekście, dzięki „,prowadzeniu dialogu w prawdzie i z poszanowaniem godności własnej i partnera" (Jan Paweł II, 1999, s. 193), w taki sposób, że mimo różnic między sobą nie stają się dla siebie wrogami. Poszukiwanie możliwości wyrazu, porozumienia się poza obrębem werbalizacji, nie zawsze jest rzeczą łatwą, dlatego ważna jest świadomość, że cisza nie zawsze musi łączyć się z deficytem słów, lecz „pozostaje formą mowy i elementem dialogu” (Sontag, 1972).

W kontekście rozważań na temat dialogu interesująca jest koncepcja dialogu w ujęciu Janusza Tarnowskiego. Wyróżnia on trzy jego aspekty (Tarnowski, 1992, s. 126-127):

- Dialog jako metoda (sposób) komunikacji, za której pośrednictwem podmioty dążą do wzajemnego rozumienia, zbliżenia się i działania (w miarę możliwości każdego z nich). 
- Dialog jako proces; zachodzi on wówczas, gdy przynajmniej jeden $\mathrm{z}$ elementów zawartych w metodzie został urzeczywistniony. Proces dialogowy może się zatem zacząć od któregokolwiek z elementów: poznawczego (rozumienie), emocjonalnego (zbliżenie się) lub prakseologicznego (współdziałanie) i stopniowo zmierzać (lub nie) do osiągnięcia pozostałych sfer.

- Dialog jako postawa oznacza gotowość otwierania się na zrozumienie, zbliżenie się i współdziałanie (w miarę możliwości) w stosunku do całej rzeczywistości. W koncepcji Tarnowskiego dialog może przybierać rożne fory (Tarnowski, 1992, s. 127):

- Dialog rzeczowy - jego przedmiotem jest wszystko, co nas otacza, a więc świat zewnętrzny. Aby zaistniał, wystarczy, by partnerzy mieli kompetencje w danym zakresie. Jego celem jest prawda wyrażająca obiektywną rzeczywistość.

- Dialog personalny, którego celem jest zjednoczenie osób zachodzące wówczas, gdy partnerzy uzewnętrzniają własne, osobiste doznania, upodobania, uczucia, radości i klęski, a także swoje najgłębsze ,ja”; zakłada on wzajemne zaufanie.

- Dialog egzystencjalny - oparty na całkowitym, wzajemnym darze partnerów z siebie. Aby zaistniał, konieczne jest przezwyciężenie samolubstwa i egoizmu. Jego celem jest wzajemne ofiarowanie przez partnerów dobra wypływającego z głębi ich egzystencji.

W odniesieniu do małżeństwa i rodziny, ich prawidłowego funkcjonowania, niezbędna jest realizacja wszystkich form dialogu. Jest to wyzwanie dla edukacji zarówno w środowisku rodzinnym, jak i szkolnym.

\section{CISZA A KULTURA DIALOGU}

Marek Dziewiecki podkreśla znaczenie rodziny, gdyż ona „stwarza najlepsze warunki, by jej członkowie uczyli się dojrzałej sztuki życia" (Dziewiecki, 2002, s. 3). Rodzina jest przestrzenią spotkania, rozwoju osób, w którym człowiek kształtuje swoją tożsamość i odkrywa swoje miejsce w świecie. Istotne znaczenie dla atmosfery w rodzinie ma umiejętność okazywania, wyrażania uczuć bez słów, cisza trwania ze sobą i przy sobie, satysfakcja ze wspólnego życia. Kultura współżycia w rodzinie buduje się nie tylko na więziach emocjonalnych, które łączą jej członków, ale jest ona dziedzictwem wyniesionym ze swojej rodziny pochodzenia i wychowania. 
Na udany związek małżeński wpływają zarówno czynniki zewnętrzne, jak i wewnętrzne, na które zarówno mąż, jak i żona mogą wywierać swój znaczący wpływ. Przy czym ,istotą partnerstwa w małżeństwie jest zasada równości kobiety i mężczyzny, opierająca się na trwałej więzi między nimi, na miłości rozumianej też jako wzajemny szacunek, na odpowiedzialności za siebie i współmałżonka, oraz na wierności” (Neugebauer, 1986, s. 4). Dużym komfortem jest umiejętność wspólnego przeżywania ciszy jako bardzo intymnej relacji między małżonkami.

Cisza potęguje wyrazistość uczuć, nadaje wartość tym sprawom, które przy użyciu słów mogłyby być pomniejszone czy wręcz zbagatelizowane. Psychologowie, socjologowie, etycy, pedagodzy, zainteresowani gamologią i familiologią, jako najważniejsze elementy związku, wymieniają m.in. właściwą komunikację i dbałość o wzajemne zaspokojenie swoich potrzeb, a także refleksyjność i takt $\mathrm{w}$ prowadzeniu dialogu. Cisza tworzy atmosferę sprzyjającą okazywaniu uczuć, a także głębszemu namysłowi odnośnie do jej wyrażania. Nie bez znaczenia jest też w małżeństwie więź seksualna ściśle powiązana $\mathrm{z}$ emocjonalną. Równie ważna wydaje się więź intelektualna, która umacnia przyjaźń i podtrzymuje wzajemną atrakcyjność partnerów. Jej podstawę stanowi więź kulturowa, wspólny system wartości, zgodność w postrzeganiu celów i dążeń życiowych.

Człowiek nie może zaznać szczęścia kosztem drugiego człowieka, depcząc jego godność i wolność, dlatego miłość winna być zakorzeniona w relacji z Bogiem. Zachowując świadomość, że miłość ma oblicze konkretnej osoby, konkretnego człowieka, rodzi się konieczność pracy nad sobą i wspólnego działania przez dialog w celu rozwoju miłości i pokoju w rodzinie.

Wiele uczuć nie wymaga werbalizacji, dlatego cisza jest znakomitym dopowiedzeniem tego, czego słowa nie mogą wyrazić czy objąć. W ciszy okazujemy swoją wdzięczność za niewypowiedziane słowa, które mogłyby zranić, zaboleć. Cisza dialogu rodzinnego to inwestowanie w rozwój emocjonalny i duchowy. Aby rozwiązać konflikty i dylematy w duchu miłości i szacunku, potrzebny jest dialog, który polega na ujmowaniu i wyrażaniu treści tak, żeby drugi człowiek był w stanie nas zrozumieć.

Cisza tworzy sprzyjające warunki do takiego słuchania drugiej osoby, aby próbować zrozumieć najgłębsze jej racje, kiedy przemawia do nas słowami, sposobem działania lub milczeniem. Dialog stanowi czasem heroiczną koncepcję dyskusji, w której łączy się gotowość do akceptacji argumentów partnera, uznając jego racje i ustępując ze swoich. 
Thomas Gordon udowadnia, że brak właściwego dialogu jest główną przyczyną konfliktu między ludźmi (Gordon, 2004, s. 52). Dialog ma znaczenie w różnych obszarach życia człowieka, jest on jednym z najistotniejszych warunków i czynników wychowania. Przez dialog istnieje szansa wzajemnego odkrywania siebie, nowych rzeczywistości, a to jest możliwe dzięki stawianiu pytań i słuchaniu, milczeniu w ciszy, by znaleźć wspólny język, który dla obu stron znaczy to samo (Szewczyk, 1997, s. 231).

Zasadą dialogu jest stworzenie wspólnej przestrzeni wzajemnego szacunku i otwartości na drugiego. Pierwszeństwo słuchania przed mówieniem, dzielenie się doświadczeniem przed pouczaniem, rozumienie przed osądzaniem. Uczestniczyć w dialogu to umieć słuchać zarówno wypowiadanych słów, jak i tych, które rozmówca zachowuje dla siebie, ukrywa w ciszy pamięci, które niewyrażone wpływają mimo wszystko na rodzaj dialogu. Zbyt wiele jest $\mathrm{w}$ dialogach małżeńskich dążenia do dominacji, udowodnienia swoich racji, a za mało umiejętności słuchania i chęci zrozumienia (Grzybowski, 1997, s. 19).

Cisza dialogu stwarza aurę niepowtarzalnej intymności i bliskości. Więzi wspólnotowe są współczesnemu człowiekowi potrzebne, bardziej niż w poprzednich pokolenia, które żyły bliżej siebie, chociażby z racji przestrzeni. W takiej rzeczywistości dzieci zdobywały umiejętność komunikowania się, rozwiązywania problemów w swojej rodzinie. Obserwowały rodziców i prowadziły dialog między sobą, niekoniecznie werbalny.

W dialogu rodzinnym ważną rolę odgrywała zgodność przekonań religijnych, która wpływała na trwałość i powodzenie małżeństwa, a także na dbałość o jego jakość. Jan Rostowski (Rostowski, 1987), rozpatruje podobieństwo religijne małżonków w aspekcie zgodnego systemu wartości i ogólnej orientacji życiowej, co sprzyja lepszemu funkcjonowaniu całej rodziny. Religijność wprowadza określone normy i zasady postępowania w rożnych sytuacjach, dlatego religijność małżonków może stać się pomocna w budowaniu atmosfery dialogu i życia rodzinnego.

\section{MILCZENIE DIALOGOWE}

Egzystencja ludzka posiada charakter dialogiczny, ponieważ „całe nasze życie jest dialogowe ze swej natury. Żyć, to znaczy uczestniczyć, pytać, słuchać i odpowiadać" (Śnieżyński, 1997, s. 135). Dialogiczność nie jest poznaniem ani uznaniem, lecz zobowiązaniem wobec innego. Małżeństwo jest 
W swej istocie uznaniem drugiego, a nawet zjednoczeniem osobowego JA i TY w osobowe MY, jest wspólnotą osób, miłości i interesów, w założeniu związkiem na całe życie, a zatem oczywistością wydaje się konieczność uświadomienia sobie dialogicznego charakteru tego związku.

Atmosfera ciszy wypełnia przestrzeń komunikacyjną, pomaga zrozumieć niepoznawalność wnętrza człowieka. Dialog jest płaszczyzną wygrywania sensów, dzięki opozycji między treściami wypowiedzianymi i niewypowiedzianymi (Wąchocka, 2005, s. 158). W ciszy rodzi się pytanie o sens, złoty środek między brakiem a nadmiarem. Pojawia się postawa wspólnego zrozumienia, aby można było uznać rzeczywiste różnice między osobami, ich potrzebami, interesami i sprawami. W dialogu rodzi się doświadczenie zdarzeń, zwykłych drobiazgów codziennego życia, potrzeba namysłu nad wspólnym życiem, próbą odnalezienia siebie w czasie, który przeminął.

Możliwość przeżycia wspomnień, traumatycznych wydarzeń przeszłości rodzi potrzebę zrozumienia siebie i bliskiej osoby, doprowadza do „narodzin" nowych relacji, nowego sposobu istnienia w rodzinie. Dialog pozostaje podstawowym czynnikiem budującym relacje między członkami rodziny, zawiera konieczność słuchania drugiej osoby.

Warunkiem aktywnego słuchania jest akceptacja ciszy, która daje możliwość usłyszenia treści i zrozumienia sensu wypowiadanych słów. Wobec niemożności uchwycenia sensu maleje waga wypowiedzianych słow. I chociaż zarówno słowa, jak i milczenie oddziałują na zachowanie, to jednak każde z nich ma swoją moc sprawczą. Milczenie i mowa wiążą partnerów ze sobą, nieraz wybiera się milczenie jako sposób określenia swojego miejsca w związku. W dialogu nie chodzi o milczące ustępstwo, które niesie porażkę partnerskich więzi, powstrzymuje przed wybuchem otwartego konfliktu, ale o takie, które daje czas do namysłu i studzenia emocji (Tanner, 1990, s. 260279). Milczenie staje się nie tylko bronią przeciwko ograniczeniom i zafałszowaniom języka, lecz również przestrzenią obecności, w jakiej jednostka szuka schronienia dla zachowania swej niezależności przed nieprzyjaznym światem (Wąchocka, 2005, s. 159).

W sytuacjach życiowych i relacjach międzyludzkich często pojawiają się problemy, trudności, które wymagają umiejętności i chęci, a także poznania sposobu ich rozwiązywania. Człowiek jest niepowtarzalny, o czym świadczą chociażby linie papilarne, stąd konieczne jest indywidualne rozwiązywanie problemów, które wymagają poznania zarówno rodzaju problemu ludzi przeżywających dramat, jak i konieczności podjęcia dialogu. 
Milczenie jest swoistym tłem mowy, planem istnienia języka, stanowi nieodzowny składnik rozmowy jako milczenie komunikacyjne, by wybrzmiały wypowiedzi partnerów (Rokoszowa, 1994, s. 27-47). Milczenie jest integralną częścią komunikacji i nie istnieją bez niego słowa bogate w treść. Stąd umiejętność słuchania w milczeniu jest warunkiem sprawnego przebiegu dialogu.

Mówienie często pokrywa niepewność, lęk, pustkę. Milczenie daje się interpretować jako forma ekspresji, wykładnik postawy egzystencjalnej. Może mieć walor pozytywny, gdy jest dobre. Istnieje takie dobre milczenie, którego „nie można uważać za nieszczęście ani traktować jak zły los, lecz którego należy szukać jako obiecującej drogi do prawdy" (Casaro, 2006, s. 125).

Milczenie nie wyklucza dialogu. Spojrzenie zastępuje słowa, wyraża o wiele więcej i wyraźniej, subtelniej to, co autentycznie czujemy. W ciszy dokonuje się porozumienie przez milczenie, które należy rozumieć jako porozumienie bez słów. Jaka forma komunikacji służy dialogowi? Kto chce go prowadzić, „powinien nauczyć się mówić i wyrażać się nie tylko przy pomocy języka koncepcyjnego i obrazowego, ale również języka symbolicznego" (Casaro, 2006, s. 125).

\section{OBLICZA CISZY MILCZENIA}

Cisza może być w różny sposób określana i nazywana, bowiem opis ciszy pozostaje na poziomie intelektualnym człowieka. Jednak dopiero osobiste doświadczenie ciszy pozwala na zrozumienie jej istoty dla relacji małżeńskich. Codzienność życia dostarcza tak wielkiej ilości bodźców słuchowych i wzrokowych, że cisza zewnętrzna przynosi ukojenie dla systemu nerwowego i uspokojenie wewnętrzne. Doświadczanie ciszy, nawet jako formy odpoczynku, sprzyja tworzeniu się dobrych relacji małżeńskich i ich umocnieniu. W podejmowaniu dialogu małżeńskiego ważne jest, żeby poznać zabarwienie emocjonalne ciszy, jaka ma miejsce w relacji małżeńskiej (cisza przed „burzą", czy cisza pojednania; cisza jednocząca, czy cisza osamotnienia rozdzielająca).

Cisza milczenia ma swoje przyczyny, może wyrażać zarówno obecność, jak i nieobecność psychiczną. Zasadniczo może być ona pozytywna i negatywna.

Pozytywna cisza milczenia (oceniana jako taka przez oboje małżonków) to sytuacja, w której małżonkowie, przebywając z sobą, nie czują ani dyskomfortu, ani zażenowania, ani innych negatywnych emocji z powodu prze- 
bywania w ciszy. Taka cisza jest doświadczeniem czegoś, co niesie ze sobą spokój, stanowi istotę dobrego związku małżeńskiego, jest okazją do refleksji, szansą wejścia w swój wewnętrzny świat. Jest to cisza, która przygotowuje do rozmowy, uspokaja, jest pewną celebracją wypełnioną sensem. Cisza może być dynamiczna, a milczenie może być najsubtelniejszą czynnością wyrażającą uczucia do drugiej osoby.

Negatywna cisza milczenia to taka, która jest niejako formą agresji. „W małżeństwie agresję można wyrażać nie tylko poprzez awantury - zauważa James C. Dobson - ale także poprzez milczenie. To złość skierowana przeciw komuś, ale także przeciwko sobie bez możliwości jej rozładowania" (Dobson, 1994, s. 74). Potocznie określa się taką ciszę mianem „ciche dni”. To czas, w którym brakuje porozumienia, osoby czują się zranione, a cisza milczenie złowrogie, wskazuje na słabość więzi emocjonalnych (Rembowski, 1986, s. 12), zaburza więź małżeńską. Długotrwałe i często powtarzające się „ciche dni” wręcz rujnują wzajemne relacje, w które wkrada się obcość i pęka jedność. Powody, które wywołują taką negatywną ciszę, są często drugorzędne, mało istotne, spowodowane najczęściej nadmiernym hałasem, przemęczeniem, chaosem, brakiem czasu, a bywa, że nawet złym stanem zdrowia. Powtarzalność „cichych dni” jest sygnałem do rozpoczęcia dialogu, gdyż przedłużająca się „separacja” oddziela małżonków od siebie (Jeziorański, 2008, s. 129). Brak spójności wskazuje na konieczność reorganizacji funkcjonowania domu zarówno w zakresie przestrzeni psychicznej, jak i fizycznej.

Każdy dialog ma z natury rzeczy charakter interpersonalny. Dialog małżeńsko-rodzinny, jak każda forma bycia razem i współpracy między osobami, wymaga wzajemnego poznania się oraz zdolności rzeczywistego porozumienia się z drugim człowiekiem. Ciszę zatem należy rozumieć jako porozumienie bez słów, jako formę wsłuchania się w drugą osobę.

Osobiste przeżywanie ciszy jest ważnym elementem ogólnego doświadczenia w relacji małżonków, bowiem może służyć wzajemnemu, głębokiemu zbliżeniu. Intymność małżeńska to inaczej satysfakcja wynikająca $\mathrm{z}$ bycia w relacji z bliską osobą. Dom rodzinny jest miejscem „wyhamowania”, pewną przestrzenią, którą małżonkowie mogą wypełnić w specyficzny dla siebie sposób.

Badania przeprowadzone przez Marka Jeziorańskiego wykazały, że rozumienie ciszy i różnorodność jej przeżywania znajduje swoje odzwierciedlenie w wewnętrznej relacji małżonków. Najbardziej znaczące dla relacji małżeńskiej jest to, aby małżonkowie mieli czas, by ze sobą rozmawiać. Nieraz 
wystarczy, by po prostu razem być, aby takie doświadczenie stawało się więziotwórcze (Jeziorański, 2008, s. 102). Czas w relacji międzyosobowej może być wykorzystany nie dla niej samej, ale też jako sposób na osiągnięcie innych celów, pozwala zbliżać się do doświadczenia głębi człowieka, zbliżyć do Boga.

Zupełnie innym, szczególnym rodzajem ciszy w kontekście życia małżeńskiego jest przemilczenie, czyli niedopuszczenie współmałżonka do wszystkiego, co dotyczy drugiej osoby, pewnego rodzaju „ucieczka” jednego ze współmałżonków przed podejmowaniem rozmowy na drażliwy temat. Wiążę się także z postawą unikającą, czasem z poczuciem winy, niską samooceną, lękiem przed odrzuceniem przez drugą osobę. To także „tajemnica”, często bolesna, wyrażająca brak zaufania do współmałżonka, rodzaj izolacji między osobami, która w konsekwencji rodzi poczucie osamotnienia w rodzinie. Cisza jednego człowieka może nie być tą samą ciszą dla drugiego. Cisza obecności i cisza nieobecności są sobie przeciwstawne. Dialog małżeński umieszcza dynamikę życia w ciszy, która ma w sobie coś z uroczystości, $\mathrm{z}$ misterium.

W analizowaniu ciszy jako składnika dialogu małżeńskiego i rodzinnego może powstać wrażenie niedocenienia roli słowa. Tymczasem słowo w każdej formie dialogu - jak przypomina Tarnowski - ma znaczenie instrumentu, który nie zawsze musi być brany pod uwagę. Może mieć miejsce przecież dialog pozbawiony słów (Tarnowski, 1992, s. 127), toczący się niewerbalnie w ciszy, która wyraża delikatność, oczekiwanie, przygotowuje do spotkania. Dzięki takiemu milczeniu możemy wyczuć wagę i głębię usłyszanych słów, nadać właściwe znaczenie wypowiadanym słowom. Cisza milczenia jest jednym z najtrudniejszych argumentów do obalenia (Wójtowicz, 2007, s. 1120). Słowa poprzedzone wewnętrznym skupieniem są bardziej wiarygodne, bardziej prawdziwe.

Rolę i wagę milczenia w dialogu małżeńskim doskonale ukazuje ks. Teodor Szarwarak $\mathrm{w}$ formie testu sprawdzającego wiedzę na temat udanego małżeństwa, którego podstawą jest umiejętne milczenie. W czasie dialogu, a szczególnie w czasie konfliktu, najmądrzejszą odpowiedzią jest milczenie. Lekarstwem na gniew jest milczenie. To, że milczę, nie znaczy, że nie mam nic do powiedzenia. Fakt milczenia nie kwestionuje obecności.

Cisza może także stanowić wstępny warunek do inicjowania rozmowy, daje możliwość namysłu, stwarza atmosferę szacunku. Pozwala uświadomić, że mamy do czynienia z jednostką niepowtarzalną, a więc różniącą się od nas temperamentem, doświadczeniem, ale mającą prawo do miłości i szacunku, jak też błędów i potknięć. 
Uporządkowane życie małżeńskie i rodzinne ma duże, by nie powiedzieć, decydujące znaczenie dla wychowania dzieci, procesu socjalizacji, poczucia bezpieczeństwa i tworzenia tożsamości. Całkowita swoboda, chaos i hałas, bylejakość życia rodzi destabilizację, chwiejność emocjonalną u dziecka, tworzy rozgardiasz pojęciowy. Konflikty są czymś nieuniknionym, w niektórych sytuacjach i okolicznościach nawet pożądanym, a ich rozwiązywanie na drodze dialogu staje się sprawdzianem relacji osobowej między zwaśnionymi stronami.

Wskazując na wychowawczą rolę ciszy, winniśmy uwzględniać takie elementy wychowania w rodzinie, jak: wpływy oparte na refleksji i wpływy niezamierzone; działania o charakterze oddziaływania i współdziałania w ciszy; naturalność więzi rodzinnej w ciszy prowadzącej do umiejętności słuchania drugiego; swoistość, niepowtarzalność i intymność ciszy (życia rodzinnego w ciszy); poczucie wspólnoty, zjednoczenia w ciszy.

Rodzina tworzy przestrzeń wychowawczą (Olearczyk, 2007), która kojarzy wpływy generowane na jej gruncie z wpływami pochodzącymi z jej otoczenia bądź emitowanymi do otoczenia. Jednym z czynników charakteryzujących rodzinę jako środowisko wychowawcze jest poziom i jakość świadomości wychowawczej rodziców, świadomość potrzeby ciszy, milczenia, ładu wewnętrznego.

\section{PODSUMOWANIE}

Obserwacja dyktatury hałasu w życiu społecznym i rodzinnym prowadzi do wniosku, że cisza odgrywa istotną rolę w procesie rozwoju w ogóle, a tym bardziej w dialogu rodzinnym. W związku $\mathrm{z}$ tym powinno być dla niej miejsce zarówno w procesie wychowania, jak i w samowychowaniu. Przyjęcie ciszy jako elementu wyższej jakości pracy nad sobą, stanowi o sile wzajemnego poznania i wpływania człowieka na człowieka, ma profilaktyczne i terapeutyczne oddziaływanie. Należy w tym kontekście wyraźnie wskazać na konieczność stwarzania odpowiednich warunków do właściwego wykorzystania ciszy w rodzinie. Zarówno predyspozycje rodziców, troska o ciszę w swoim życiu, jak i odpowiednie warunki zewnętrzne zdecydują o możliwościach takiego wykorzystania ciszy, która będzie przynosiła oczekiwane owoce.

Powyższe refleksje nie pretendują do wyczerpania całości zagadnienia pedagogiki ciszy. Pozostaje wyrazić nadzieję, że staną się one zaproszeniem 
przedstawicieli różnych dyscyplin naukowych i sztuki do refleksji nad rolą ciszy w globalnych procesach świata.

\section{BIBLIOGRAFIA}

BARAN, B. (1991). Filozofia dialogu. Kraków: Znak.

ChmielewsKa, J. (1998). Jak wytrzymać z mężczyzną. Warszawa: Wiedza i Życie.

Chryssavgis, J. (2007). W sercu pustyni. Duchowość ojców i matek pustyni, tłum. M. Chojnacki. Kraków: Wydawnictwo Uniwersytetu Jagiellońskiego.

Dobson, J. (1994). Emocje: czy można im ufać? Warszawa: Vocatio.

DzIEwIECKI, M. (2002). Miłość przemienia. Przezwyciężanie trudności w matżeństwie $i$ w rodzinie. Częstochowa: Edycja Świętego Pawła.

Gordon, T. (2004). Wychowanie bez porażek w szkole. Warszawa: Instytut Wydawniczy Pax.

GrZybowski, J. (1997). Wprowadzenie do dialogu. Kraków: Wydawnictwo M.

JAN PAweŁ II (1999). Drogowskazy dla Polaków Ojca Świętego Jana Pawła II, t. 1: Najważniejsze przemówienia i wypowiedzi (poza pielgrzymkami), red. M. Czekański, Kraków: Wydawnictwo M.

JEZIORAŃSKI, M. (2008). Kategoria ciszy w komunikacji dorostych o rożnym poczuciu zadowolenia z matżeństwa. Praca magisterska napisana na seminarium z Pedagogiki Rodziny, pod kier. D. Opozdy. Lublin: Wydawnictwo KUL.

KAwUlA, S. (1975). Świadomość wychowawcza rodziców: stan aktualny, niektóre uwarunkowania i skutki oraz perspektywy. Torun: Wydawnictwo UMK.

M. CASARo (red.) (2006). Milczenie Boga, milczenie człowieka. Kielce: Wydawnictwo Jedność.

Neugebauer, K. (1986). Refleksja historyczno-światopoglądowa. Problemy Rodziny, 1, 4.

NiedZiaŁkowsKi, S. (1998). Świat mimu, tłum. E. Pastecka. Warszawa: Wydawnictwa Szkolne i Pedagogiczne.

OleArCZYK, T. (2007). Sieroctwo i osamotnienie. Pedagogiczne problemy kryzysu wspótczesnej rodziny. Kraków: Wydawnictwo WAM, Wyższa Szkoła Filozoficzno-Pedagogiczna Ignatianum.

OlearczyK, T. (2010). Pedagogia ciszy. Kraków: Ignatianum.

OlEARCZYK, T. (red.) (2014). Cisza w teorii i praktyce pedagogicznej. Obraz interdyscyplinarny Kraków: Oficyna Wydawnicza AFM.

OleArCzyK, T. (2016). Cisza w edukacji szkolnej. Kraków: Wydawnictwo KAF.

OlEARCZYK, T. (2013). Rodzina między starym a nowym paradygmatem. Rużemberok: VerbumVydatel'stvo Katolickej Univerzity.

OlEARCZyK, T. (2014). Trwałość (rodziny) w zmienności (tradycyjna i nowa rodzina). W: E. OsEWSKA, J. STAla (red.), Nauki o rodzinie w stużbie rodziny. Kraków: Wydawnictwo Naukowe Uniwersytetu Papieskiego Jana Pawła II.

OlearCZyK, T. (2019) Środowisko wychowawcze rodziny Hanny Chrzanowskiej. W: E. OsEWSKA, J. STAla (red.), Rodzina w spoleczeństwie - relacje $i$ wyzwania (s. 247-262). Wydawnictwo Naukowe Uniwersytetu Papieskiego Jana Pawła II.

OlearczyK, T. (2020). Silance and Human Developement (Cisza w rozwoju człowieka). Pedagogia Christiana, 1(45), 53-65. Torun: Wydawnictwo UMK. 
RemBowsKi, J. (1986). Rodzina w świetle psychologii. Warszawa: Wydawnictwa Szkolne i Pedagogiczne.

Rokoszowa, J. (1994). Milczenie jako fakt językowy. Biuletyn Polskiego Towarzystwa Językoznawczego, 50, 27-47.

Rostowski, J. (1987). Zarys psychologii małzeństwa. Warszawa: Państwowe Wydawnictwo Naukowe.

Sontag, S. (1972). The Aestheties od Silance. W: S. Searc, W.G. Lord (red.), The Discontinuous Universe. Selected Writing in Contemporary Consciousness. New York-London: Basic Book.

SZARWARK, T. (2004). Test sprawdzajacy wiedzę na temat udanego malżeństwa i rodziny, Kraków: Wydawnictwo ITKM.

SzCzepan, M.(1984). Rozmowy o milczeniu. Kraków: Wydawnictwo OO. Karmelitów Bosych.

SzEwCZYK, W. (red.) (1997). Przygotowanie do matżeństwa. Warszawa: Michalineum.

ŚNIEŻYŃSKI, M. (1997). Zarys dydaktyki dialogu. Kraków: Wydawnictwo Naukowe PAT.

TANNER, D. (1990). Silence as Conflict Management in Fiction and Drama: Pinter's „Betrayal” and a Short Story „Great Wits”. W: A.D. Grimshaw (ed.), Conflict Talk (s. 260-279). Cambridge: Cambridge University Press.

TARnOwSKi, J. (1992). Pedagogika dialogu. W: B. ŚLIWERSKI (red.), Edukacja alternatywna - dylematy teorii i praktyki (s. 126-127). Kraków: Impuls.

Tischner, J. (1982). Myślenie wedtug wartości. Kraków: Znak.

WĄ̨CHOCKA, E. (2005). Milczenie w dwudziestowiecznym dramacie. Kraków: Księgarnia Akademicka.

WIEJA, A., WiEJA, H. (2002). Matżeństwo, o jakim marzymy. Ustroń: Koinonia.

Wójtowicz, K. (2007). Glosarium czyli zbiór 1111 exemplów i 5555 sentencji, w cztery ciagi tematyczne ułożone. Kraków: Wydawnictwo Alleluja.

\section{CISZA W DIALOGU RODZINNYM}

\section{STRESZCZENIE}

Codzienność życia dostarcza tak wiele bodźców słuchowych i wzrokowych, że doświadczanie ciszy wydaje się niezbędne $\mathrm{w}$ tworzeniu dobrych relacji małżeńskich $\mathrm{i}$ ich umacnianiu. Rodzina jest przestrzenią spotkania, rozwoju osób, w którym człowiek kształtuje swoją tożsamość i odkrywa swoje miejsce w świecie. Cisza i milczenie, różnie określane, są nieodzowne w kształtowaniu zdrowej atmosfery rodzinnej, w procesie rozwoju w ogóle, a tym bardziej w dialogu rodzinnym. Wartość ciszy powinna być doceniana w procesie samowychowania, jak i wychowania młodych pokoleń.

Słowa kluczowe: milczenie; uważność; cisza; słuchanie; dialog rodzinny; cisza milczenia; hałas. 


\section{SILENCE IN A FAMILY DIALOGUE}

SUMMARY

Everyday's life brings so many visual and auditorial external stimulus that experiencing silence seems to be essential to create good marital relationships and strenghten them. A family is a space of meeting, development of people in which man creates his identity and discover his own place in the world. Silence and calmness, differently defined, are necessary to shape a good family atmosphere in development process, all the more in a family dialogue. The value of silence should be appreciate in a self-education process as well as upbringing young generation.

Keywords: silence; mindfulness; listening; family dialogue; stilness of silence; noise. 